\title{
1. Legal theory: from intellectual property to informational goods
}

Patents and copyrights approach, nearer than any other class of cases belonging to forensic discussions, to what may be called the metaphysics of the law, where the distinctions are, or at least may be, very subtle and refined, and, sometimes, almost evanescent.

(Folsom v. Marsh, C.C.D.Mass. 1841, No. 4,901)

What is this intellectual property or what are these intellectual rights? In what does their intellectuality consist? How should we understand the division between the intangible immateriality of the created work or the innovative invention and their embodiments in tangible material objects? What is an idea in the sense of patent and copyright law? In this chapter, we will deal with some of the answers given to these questions about this 'metaphysics of the law', along with a host of different theoretical positions. By way of a prelude to our topic, we will start here with an encounter with the issues that intellectual property rights raise in what is called the information society. In section 1.2, we will provide the concise kind of introductory view on intellectual property that we get by reading the textbooks on the matter and the articles in which the polemics about the use of the term are discussed. In section 1.3, we will engage with studies of the historical development of intellectual property and show the philosophical positions that have been used to ground this legal regime. In section 1.4, we will engage with the shifts in legal doctrine from intellectual property, through immaterial goods to informational goods. The accounts provided here do not aspire to be exhaustive of these subsequent topics. This would have required a different kind of book. They will instead rather serve to introduce the broad themes and developments of the distinct regimes of intellectual rights. They will also provide an opportunity to study different approaches in explaining concepts of intellectual property. 


\subsection{INTELLECTUAL RIGHTS IN THE INFORMATION SOCIETY}

Intellectual rights have become a prevalent legal regime in modern society. A frequent glance at the technology sections in newspapers generally gives a good impression. We read about lawsuits of copyright organizations against file sharing sites like the Swedish 'Pirate Bay' and against internet providers for hosting connections to all kinds of movies, images and films. We further read about the founding of European Pirate parties that protest against excessive copyright protection and urge the protection of the public domain. There are also several property controversies about online social network site Facebook, ranging from its assertions to possess rights to all the users' photos and videos, to Russian hackers offering 1.5 million Facebook profiles for sale on the black market. There are also some interesting articles about two Dutch court cases on affairs of theft of virtual property, judging that virtual items have been stolen within an online computer game and a virtual world. Apart from copyright and information technologies, there are also several articles about biotechnology and patent law. The practice of patenting genetically modified products, including living organisms, cell lines and genes, has spurned a controversy in the US, sometimes resulting in court cases. ${ }^{1}$ Patents on nanotechnologies seem to be next in the line of fire. The latest development of 3-D printing is also bound to give rise to a whole new dimension of copyright issues.

All these issues have to do with intellectual rights and the emergence of new information technologies. Information has fast become an organizing concept of the international economy and its control and ownership channels important power relations in society. ${ }^{2}$ The last decade has seen the emergence of a discourse on the convergence of technologies. Formerly separate domains like nanotechnology, biotechnology, information and communication technology and neuro-technologies are coming together in a single paradigm of engineering of information in which the material medium becomes an interchangeable carrier of intangible information. ${ }^{3}$ This convergence had its precursors in discourses on media and information technologies. Some theorists of media described how different media with their own autonomous data format,

1 Diamond v. Chakrabarty, 447 US 303; Association for Molecular Pathology v. Myriad Genetics, No. 11-725.

2 The question about the legal status of information thus becomes all the more relevant (Gutwirth, 1993).

3 Nordmann, 2004. 
like writing, film, photography and phonography, were transformed by the advent of digitization through which they all converged into the single bit format. Different media have become interchangeable carriers of informational codes (Kittler, 1986). The medium might have become the message, but the only message is that the medium has made itself irrelevant.

In this context, some have spoken about the 'homologization of information', which unites contemporary problems of ethnic cultures, software industries and the human genome project and results in an increasing decontextualization of information from its particular medium and location (Boyle, 1996). In Big Data 'informatics', raw data are turned into meaningful information through data mining algorithms. In molecular biology discourses, genetic issues have also been restated in terms of information. Through the mobilization of book metaphors the reproduction of DNA has been framed as a bio-material variant of printing in which an intangible informational code is transferred from one material medium to another (Pottage, 2009).

This framing of informational issues has pushed the regimes of intellectual rights centre stage. The difference between immaterial information and material mediums or carriers is precisely the kind of difference on which these regimes are grounded. ${ }^{4}$ Intellectual rights protect intangible inventions or works that have become expressed in tangible objects (like amino acids and hard disks). This has provided an ideal basis for using these legal regimes to regulate information technologies. If information has become the organizing concept of knowledge-based economies, intellectual rights have become its legal 'property' regime, 'intellectual property is the legal form of the information age' (Boyle, 1997, p. 90). The ontological framing here turns into 'ontological politics', 5 or rather ontological juridics. Some have pushed the boundaries of the frame, or have even inverted the relation between frame and framed in claiming that that 'each work has the character of information'. Both are immaterial goods with a structured form of expression capable of transmission for communication (Hugenholtz, 2005).

4 For a critique of the attempts to frame information as immaterial and an account of the material histories of computing, see Blanchette, 2011. Stiegler is more sweeping when, in the context of the web as a medium, he states that "nothing is immaterial' (Stiegler, 2012, p. 5). This statement cannot serve as a point of departure, since immateriality is dismissed tout court at the outset.

5 Mol \& Law, 1994. 


\subsection{INTELLECTUAL PROPERTY AND ITS CRITIQUE}

The rhythm of the information society is one of increasing speed in striving towards the ideals of real-time reaction and future anticipation. It is time to decelerate in order to find a closer resonance with the rhythms more proper to legal discourse. Law slows things down, it temporizes. This is not an expression of its incapacity, the fact that it is badly organized, or that it continuously is lagging behind the developments of society. It is an expression of its own mode of operation.

We will start with a first introduction to intellectual property, the kind that we get when reading legal textbooks or encyclopedias. Although these are always situated in a particular legal tradition, they often introduce the field in general terms in ways that provide a unification of the subject matter at hand. Intellectual property, geistiges Eigentum, propriété intellectuelle, is a term that is used to group together legal regimes like patent, copyright and trademark law. In the next section, we will see how the term served as a rallying cry for the establishment of a new legal regime when the first copyright laws were enacted at the end of the eighteenth century. Whether the term 'intellectual property' really ever established itself as a legal concept in the legislations, jurisprudence or legal theory of the nation states in the following centuries up until the mid-twentieth century is controversial. ${ }^{6}$ Nevertheless, with the founding of the World Intellectual Property Organisation (WIPO) in 1967 these different legal regimes merged under the sole header 'intellectual property', which installed the term as a general overarching concept in international law. The term was fortified by the Treaty on the Trade-Related aspects of Intellectual Property Rights (TRIPS) in 1994 and, from then on, further trickled down into European law and national legislations. The different legal regimes of copyright, patent and trademarks are all said to belong together, because they all grant exclusive rights on the 'creations of the human mind'. The purpose of all these rights is to protect 'the integrity of intellectual objects' ${ }^{8}$

Critics have pointed out that there is a problem with the use of the word

6 With regard to European law Goetting, 2006 supports this thesis, whereas Peukert, 2011 rejects it.

7 See for example the textbook of Wichers Hoeth, 2007 on intellectual property. This view is acknowledged by WIPO.

8 Spinello \& Bottis, 2009, p. 4. 
'property' for referring to the regimes of copyright and patent. There are significant differences between property and intellectual property with regard to the kind of right and the object of the rights. Property rights are conceived as the most absolute exclusive right of a person on a thing. The rights granted in patent law or copyright however are more limited in duration and scope, and for this reason they have also been called temporary intellectual monopolies instead of property rights. Furthermore, in criminal law there are also important differences between intellectual rights and property rights. Contrary to common language a violation of intellectual rights does not constitute 'theft'. The insistence on such terms as 'property' and 'theft' reveals a certain rhetoric of propertization, which is fed by the content industries and their representative author organizations $^{9}$ and by WIPO itself. In this way, a whole range of issues is located within a discourse of appropriation and its concepts are employed to remove the limitations of such 'intellectual' objects.

Furthermore, it has been pointed out that the legal objects of property rights and intellectual property rights are fundamentally different. The object of property rights (in Continental law) is a material thing, a Sache, zaak, chose, corpus mechanicum. The object of intellectual rights is a corpus mysticum or Immaterialgut. Contrary to tangible property like land, intangibles are non-rivalrous. A work or an invention can be made available to third parties without diminishing their use value. Thomas Jefferson already remarked that ideas are 'like fire, expansible over all space, without lessening their density at any point, and like the air in which we breathe, move, and have our physical being, incapable of confinement or exclusive appropriation. Inventions then cannot, in nature, be a subject of property' (Jefferson, 1813, p. 333). ${ }^{10}$

The legal regimes of copyright law and patent law are thus very different from the legal regime of property, both qua incorporeal object and qua limited nature of the granted rights. These regimes however also have important differences from each other, which oppose their assimilation to a singular regime of 'intellectual property'. The term lumps together fields of rights that each had their independent historical trajectories and involve very different sets of law. Each of these legal regimes has had to invent its own techniques for the demarcation of

\footnotetext{
$9 \quad$ Lemley, 1997.

10 This is also the reason the infamous 'tragedy of the commons', which occurs when a common resource like land is overused due to the fact that too many people have entitlements in it, will not take place with intangibles. In fact in some fields, granting too many intellectual rights has resulted in a 'tragedy of the anticommons' (Heller \& Eisenberg, 1998, p. 698).
} 
its intellectual object. All these differences are obscured by the use of this general term 'intellectual property'. ${ }^{11}$ Curiously, whereas the notion of 'property' is heavily debated, what is little or not discussed is the notion of 'intellectuality'. 'Intellectuality' and 'immateriality' have played an important role both in the conceptualizations of the legal regimes of copyright and patent law and to a certain extent also in that of trademark law. By focusing on the specificities of these regimes, we can come to understand the figures of intellectuality at stake in creation.

\subsection{HISTORICAL AND PHILOSOPHICAL DEVELOPMENTS OF INTELLECTUAL PROPERTY}

The author has played the role of the regulator of the fictive, a role quite characteristic of our era of industrial and bourgeois society, of individualism and private property.

(Foucault, 1979, p. 159)

Gutenberg's invention of the printing press with movable type around 1440 , and the subsequent spread of printing presses to urban centres throughout European countries, has had important consequences. It enabled what has been called the 'Gutenberg Galaxy' (McLuhan, 1994) or the 'printing revolution' (Eisenstein, 2005), which led to transformations in many disciplines amongst which are law and its many regimes. ${ }^{12}$ The printing press mechanized the mode of book production and led to an enormous increase in output. There was a marked proliferation of copies of works on the market and an expansion of a reading public. In order to safeguard printers and also authors against these practices of copying, a system of printing privileges was created modeled on the old legal figure of commercial monopolies in the fiteenth and sixteenth centuries. These monopolies were granted by the state on all printing

\footnotetext{
11 Stallman, 2006.

12 Eisenstein describes the many consequences of the shift from the technology of script (manual copying) to print. The possibility of producing more uniform texts and distributing these over large areas influenced law, language, science, education, memory and art. Access to the same legal codes made it possible to apply the 'same' law on a more broad scale, unifying the legal regime within a certain territory. The quantity of available texts revealed conflicts between texts and spurred a process of cataloguing, indexing and rationalization leading to the extension of old criteria of consistency and unity (Eisenstein, 2005).
} 
activities and did not discriminate between classical works, dictionaries, calendars and new creations. They also led to state censorship of works. In the seventeenth century, the system of privileges became untenable. The demand for books had risen dramatically, partly due to a growing literacy in the middle classes. The existing system of privileges limited the supply of books that was available at the time. The result was an emergence of illegally printed books that flooded the market. This problem became very prevalent in the eighteenth century as a problem that required solution. ${ }^{13}$ A public of differently affected groups in different countries and of different professions - lawyers, writers, printers, thinkers and politicians - were engaged by this problem and formulated their wide-ranging responses. In Germany, they ranged from Luther, Putter, Kant, Fichte, Hegel to Schopenhauer and further included Diderot, Voltaire and Condorcet in France and Young and Blackstone in England. ${ }^{14}$ Eventually, the idea of intellectual property became decisive for the abolishment of the privilege system and for the development of authorial rights. The act of copying of works was no longer only seen as a moral offensive, as it was in the time when Luther compared the illegal printers of his bible translations to thieves and robbers in the sixteenth century, but was now seen as an infringement of the law, the legal source in question being the natural law. ${ }^{15}$

In order to understand these European developments in more detail, we will turn to historical accounts of the role of the 'author function' in the emergence of copyright in England, France and Germany, ${ }^{16}$ which transforms discourses of writing into objects of appropriation and ownership (Foucault, 1979). ${ }^{17}$ In this context, we will study several thinkers whose works have been an event in this emergence of intellectual property, and

13 Eisenstein states that since 'early printers were primarily responsible for forcing definition of literary property rights, for shaping new concepts of authorship, for exploiting bestsellers and trying to tap new markets, their role in this celebrated quarrel should not be overlooked' (Eisenstein, 2005, p. 96). By providing access to more identical copies of texts, the printing technology mediated a sharper distinction between 'the fresh and original as against the repeatable and copied' (p. 58).

${ }_{14}$ For an account of the 'prehistory' of the development of intellectual property before these times, see Buydens, 2012.

15 Ulmer, 1960, pp. 49-50.

16 For an account of the emergence of copyright in the US, see Jaszi, 1991.

17 Barthes had proclaimed that writing implies the destruction of its point of origin, which would provide a certain unity to the work, i.e. it implies 'the death of the author' (Barthes, 1977). Foucault responded to this disappearance of the subject in writing in order to analyze the space hereby left empty. 
follow how they constitute these rights in intellectual works in response to the problems of illegal printing practices. ${ }^{18}$

\section{Copyright in England}

The concept of the modern proprietary author in England has been described as a contraction of three different developments: the fact that there was sufficient economic demand for books on the market to commercially uphold a system of continued book production; the presence of the concept of the romantic author as the originator of works; the presence of a Lockean labourer's discourse on property (Rose, 1988). The 'English struggle over copyright' took place through polemical pamphlets and some landmark legal court cases. The pamphlet writers were engaged by the struggle about the nature of copyright and literary works between upcoming provincial booksellers and London booksellers who wanted to maintain their dominant position in English book trade. The London booksellers wanted to establish that copyright was like a perpetual property right in corporeal things recognized under common-law, whereas the provincial booksellers denied this position. These tensions were eventually solved in the important court cases Millar vs. Taylor and Donaldson vs. Beckett, in which the judges acknowledged the common law right of the author to control his publication, but rejected a perpetual copyright. Within this landscape, we will follow the course of this debate and how the problems of authorial creation and illegal printing were dealt with in the Tonson $v$. Collins case in 1762, and how the author's rights on literary composition were herein constituted either as a property right on an incorporeal entity, or as a right to perform certain actions with regard to a text.

The issue at stake in Tonson $v$. Collins was the reprint by Collins of The Spectator by Addison and Steele, once printed by London bookseller Tonson. ${ }^{19}$ Tonson's attorney, the famous jurist Blackstone, argues that the author of a literary work has the exclusive right to make copies of

18 Diderot makes an interesting orienting remark about the nature of such problems: 'We must not imagine that things happen without cause, or that wise men are unique to our own age, or that the public interest was less well-known or less highly-esteemed by our predecessors than by ourselves. Seduced by systematic ideas, we attack their behaviour, and we are all the less inclined to recognize their prudence because the problem which they solved by their legislation no longer affects us' (Diderot, 1763, my accents). This provides an orientation for how to approach the writings of the thinkers mentioned above: we will look at the traits of the problems of illegal printing in different countries and how these thinkers formulated their conceptual distinctions as responses.

19 For a more thorough exposition of this case, see Deazley, 2008. 
this work. In order to institute this right he refers to the Lockean argument for justifying property rights. Locke has argued that since man has a property in his own person and thus in his bodily actions, by his bodily labour, man mixes a part of himself with things in their natural state and thereby appropriates them. ${ }^{20}$ Blackstone extends Locke's argument to literary works: permanent property rights may be acquired both through occupancy by bodily labour as by mental labour. There is thus the 'same right of occupancy in ideas as in a field, a tree, or a stone'. He continues by introducing the following differentiation:

A literary composition, as it lies, in the author's mind, before it is substantiated by reducing it into writing, has the essential requisites to make it the subject of property. While it is dormant in the mind, it is absolutely in the power of the proprietor. He alone is intitled to the profits of communicating, or making it public. The first to which, is cloathing our conceptions in words, the only means to communicate abstracted ideas (Court of King's Bench, 1762, Tonson v. Collins, 322-3).

By publication the author does not relinquish his right to make profit by his work, merely the exclusive privilege to be the only person to orally recite the work 'to the Ear'. Instead, by the acts of writing or printing that substantiate his ideas in paper and ink, the author 'has constituted a substitute in his stead, which speaks perpetually to the eyes of every reader' (p. 324). Blackstone later condenses several of these elaborate case-based arguments in the famous 'Commentaries', his systematization of English common law (Blackstone, 1897). Both copyright and patents are here categorized under the chapter 'Title to things personal by occupancy', together with property in corporeal things like goods, movables, light, air, water, animals or fruits.

Yates, Collins' attorney, to the contrary emphasizes the specific nature of this mental property that is in dispute. He compares it with the known species and principles of property and finds it lacking. First, this mental property is incapable of separate and exclusive enjoyment (the argument of non-rivalrousness) and it is not capable of possession. The books published by Collins - the 'paper and ink' - never belonged to Tonson, merely the ideas which the book communicates and these ideas, upon publication, have become in possession of everyone 'like land thrown into the Highway'. The author thus merely has property in his private 'incorporeal ideas' before publication. Furthermore, this mental property lacks the essential requisites of real property since it is neither visible nor

20 Locke, 2005, 27. 
material, whereas it 'should be something, that may be seen, felt, given, delivered, lost or stolen' (Tonson v. Collins, p. 338). Yates thus obstructs Blackstone's attempts to make a literary work into a separate kind of incorporeal entity that can be occupied and possessed and could constitute the subject matter of a property right. Instead, we are here not dealing with property rights to things, but with rights to perform certain actions: to publish ideas to the public. In this sense they resemble temporary privileges like patents, since 'both are the productions of genius, both require labour and study, and both, by publication, become equally common to the world' (p. 339).

In his reply, Blackstone denies this comparison. He states that the identity of the literary work resides in its 'style and sentiment', whereas the 'paper and print' are mere accidents. 'Every duplicate therefore of a work, whether ten or ten thousand, if it conveys the same style and sentiment, is the same identical work' (p. 343). By requiring that the subject of property has to be substantial, palpable and visible, Yates has failed to distinguish between corporeal and incorporeal rights that can both be the basis of property. Later in his Commentaries, he consolidates this distinction. Interestingly, he describes incorporeal hereditaments as 'something collateral' to corporate things:

Corporate hereditaments are the substance, while incorporeal hereditaments are but a sort of accident, which inhere in and are supported by such substance, and may or may not belong to it, without any visible alteration therein. Their existence is merely in idea (Blackstone, 1897, p. 174, my accents).

Although Blackstone has constituted literary works as incorporeal entities subject to property rights, he still assigns them a rather marginal status in the property spectrum in relation to corporeal substances. ${ }^{21}$

\section{Droit d'Auteur in France}

In France, there was a different mix of historical developments. Although there also was a great market for commercial book trade, the concept of the proprietary author arose in the period in which France politically moved from an absolute monarchy to the French Revolution (Hesse, 1990). Under the Old Regime, printing privileges had been granted to certain publishers, which also functioned as a censoring device. In the French Revolution, the system of privileges of the Old Regime was

21 In Chapter 6, we will see how Hohfeld criticizes Blackstone's distinction, stating that all legal interests are incorporeal. 
overthrown. This resulted in a wild growth of pirated and libellous publishing. Laws were passed that made it compulsory for authors to sign their texts in order to be held accountable for their contents. Limited rights of literary property were initially created for these purposes. Only later, when the issues of literary property and libel were separated, could the former be represented as promoting public enlightenment. Furthermore, this concept of literary property emerged within a discourse on property that diverged from the one in England. Although, the debate on literary property was also based on the Lockean conception of property, it capitalized upon the tension between the labourer's conception of appropriation and the Lockean proviso of the commons free for all to use. ${ }^{22}$ These two opposite positions were taken by d'Héricourt and Diderot, who defended an eternal property right on ideas as natural creations by the individual mind, and by Condorcet, who defended a conception of a public domain of ideas discovered in nature by the senses.

These writers were also engaged with the French version of the 'battle of the booksellers' of provincial booksellers against the literary monopolies of royal printing privileges held by Parisian booksellers. At stake in this debate are the relation of privileges on literary works to property rights in land and goods on the one hand and notions of the public interest on the other. D'Héricourt, jurist and attorney of the Parisian faction, argued in a letter that the author's rights on his literary work could not be distinguished from a property right on land, houses or movables, but are 'of the same nature' and thus 'subject to the same Laws' (d'Héricourt, 1725). Both rights are justified by the Lockean argument as fruits of the (creative) labour of the author. Royal privileges did not constitute the author's right, but merely served as 'authentic authorizations' of pre-existent works. Diderot, who was asked to advocate the Parisian cause, further develops d'Héricourt's distinction between literary property and landed property in a famous passage:

Indeed, what can a man possess, if a product of the mind, the unique fruit of his education, his study, his efforts, his time, his research, his observation; if the finest hours, the finest moments of his life; if his own thoughts, the feelings of his heart, the most precious part of himself, that part which does not perish, that which immortalizes him, cannot be said to belong to him? What comparison can there be between a man, the very substance of a man, his soul, and a field, a meadow, a tree or a vine which, at the beginning of time, nature offered equally to all men, and which the individual claimed for himself only by cultivation, the first legitimate means of possession? Who has more right than the author to use his goods by giving or selling them? (Diderot, 1763, my accents). 
Diderot uses a cultivation argument for acquiring property in land and goods and applies it to products of mental labour. This justification could be seen as an epitomization of Locke's labourer theory of property, the backbone of which was a personhood based argument. In contrast to the things of external nature ('a field, a meadow, a tree or a vine') that first have to be mixed with personhood, a literary work is the direct product of mental thoughts and ideas that make up the very substance of human personhood. Therefore, the Lockean argument applies even more forcefully to literary works.

Condorcet introduces a different position on the battle of the booksellers based on the freedom of the press. He argues that the regulation of book printing by royal privilege and preceding censorship restricted the way in which ideas and truths could freely circulate amongst the reading public and thus hampered the progress of Enlightenment:

it is thus only for the expressions, for the sentences, that privileges exist. It is not for the issues, the ideas: it is for the words, for the name of the author. Hence their objective is not to preserve for an inventor the price of the useful discoveries he has made, but to put it up for sale at a higher price with the agreeable appearances which he has imagined (Condorcet, 1776, p. 311, my accents).

Ideas and truth inhere in nature and can be discovered by different people and thus do not merit legal protection by privileges. ${ }^{23}$ Only the particular linguistic expression given to those ideas by the author can be protected. This personal expression of the author is rather negatively seen as an 'agreeable appearance' to drive up the price of the work in relation to its 'natural price' obtained in unhampered free circulation.

The eventual law passed by the legislative assembly in 1793 during the French Revolution can be seen as a compromise between the positions of Diderot and Condorcet (Hesse, 1990). On the one hand, the law recognized the inviolable rights of an individual on his creation. On the other hand, this right was temporally limited instead of eternal since in the final instance such works served to promote Enlightenment, which could only be achieved by a free circulation of ideas and knowledge.

\section{Urheberrecht in Germany}

Germany had its own mix of developmental lines that were contracted in the concept of the proprietary author: a romantic conception of the originary author (vs. craftsman or divine inspiration/gift), an unauthorized

23 Hesse, 1990. 
market of commercial reprinting of books, a transition from authors writing under limited patronage to writing as a separate occupation under the democratic patronage of the marketplace. This was a gradual transition, no revolution as in France, within a nation scattered over many different states that all came up with their own copyright laws. The practices of book piracy, actively supported by mercantilist economic policies of the German states, eventually spawned the 'debate over the book' in a period between 1773 and 1794 in which lawyers, publishers, poets and philosophers were all engaged. The new concept of the proprietary author emerged exactly at this interplay of the economic-legal and the estheticphilosophical levels of discourse (Woodmansee, 1984). ${ }^{24}$ Mercantilists emphasized that a book was not an ideal thing that could be owned by its author, but was a physical thing of ink and paper owned by its publisher. In order to ground property claims of the author on his creation, it was thus necessary to constitute the book as something immaterial. This brings us to the romantic concept of the originary genius. In the Renaissance, the figure of the author was an instable marriage between the incompatible concepts of the craftsman and of the divinely inspired. The author was here seen as a vehicle of creation, rather than as someone personally responsible for it. In the eighteenth century this divine source of inspiration became internalized in the new concept of the creative genius and the original work (Panofsky, 1968). This was to an important extent due to the reception of the ideas of Young in Germany, which answered to the need of German writers to establish ownership through copyright laws. ${ }^{25}$ They also enabled theorists and philosophers of the genius period to effect a new conception of composition. In this context, we will treat the positions of Fichte and Schopenhauer within the debate on illegal printing and the immaterial nature of the work.

Fichte responds in an essay to the question of the legitimacy of book copying raised in a journal article by publisher Mr Reimarus. At stake is the issue of determining whether a writer has an exclusive property right to the book he wrote, which Reimarus denies. Fichte, considering

24 Woodmansee does not really treat the legal aspects of the debate. According to Ulmer, the property discourse on natural law formed the background for the development of copyright or intellectual property doctrine more generally (Ulmer, 1960), perhaps with the exception of Kant, 1785 who argued authorial rights are personal rights.

25 Rose has commented on how Young's ideas had not yet been present-athand in England itself when the struggle over copyright was performed, withholding the possibility of offering lines of argumentation based on his romantic conception of the creative author (Rose, 1988, pp. 61-2). 
the difficulty that no similar situation exists, takes up the challenge by introducing some crucial distinctions with regard to books. First, he distinguishes between their physical (körperliche) aspect as printed paper and their intellectual (geistiges) aspect. The ownership of the printed paper is indeed transferred upon the purchase of a book. The question is whether the same applies to the intellectual aspect. To answer this question, Fichte further divides the intellectual aspect of the book

into a material (materielle) aspect, the content of the book, the ideas it presents; and the form of these ideas, the way in which, the combination in which, the phrasing and wording in which they are presented (Fichte, 1793, p. 447).

These are crucial distinctions which have come to dominate much of copyright doctrine. Not only can one distinguish a physical side of the book consisting in its paper and ink, but one can also distinguish its content consisting of ideas, and its form consisting in the way these ideas are combined and presented. Whereas ownership of the physical book can be transferred by purchase, the ideas a book contains are common property due to their ideal nature and cease to be the author's exclusive property upon publication. The form of ideas however can never be appropriated because everyone has their own way of making and connecting them and it is highly improbable that two persons will follow the same course of ideas (Ideeengang). This remains the exclusive property of the writer.

It is interesting to also look at Schopenhauer's writings on genius and author's rights, since he provided inspiration for Kohler's theory of immaterial goods, which will be treated in the next section. In a very short piece, Schopenhauer argues that the work of ideas (Gedankenwerk) is, if anything, the property of the author, which is to be protected by law. Since this property is not physical, but intellectual or immaterial, it cannot be treated according to the rules that apply to physical property. The author must be free to communicate his work, without seeing his property rights endangered. Since this communication can only happen through material means which expose his property to theft, this has to be prevented by laws with a special character. Their object in this singular case is an intangible property which remains the same throughout the material media of communication, which they enter merely 'per accidens' (Schopenhauer, 1864). This view of the work as an immaterial object has to be understood in the light of Schopenhauer's philosophical writings on art and genius. In his vision, art, being the work of genius, repeats the eternal Platonic Ideas as the original unchanging forms. Through the process of contemplation that is essentially perceptive, non-conscious and organic, the genius retains the 
Ideas and repeats them in an original work. ${ }^{26}$ The being of the work of art thus consists in the repetition of eternal ideas, which themselves remains unchanged in this process. These works, as individual things, relate to an Idea 'as an archetype to its copies' (Schopenhauer, 1954, Book III).

In the course of a century, the issue of the legality of book printing had spawned ongoing debates about the nature and legal protection of literary works, in which they gradually became constituted as full-fledged substantial incorporeal entities with their own legal regime of protection. In Blackstone, literary works as incorporeal entities became the subject of property rights, but were still deemed collateral accidents to corporeal substance that formed the basis of the property regime. Through the arguments of d'Héricourt and Diderot the rights of the author on his work become subsequently levelled in importance with regard to corporeal property rights and even exceeded the latter. In Schopenhauer, this reversal becomes complete: the incorporeal work of ideas becomes the substance, whereas the material medium of communication has become a mere accident.

\section{Patents}

The discourse on intellectual property mainly developed in the context of the emergence of copyright. Patents and trademarks had different independent paths of historical development. In order to understand why these legal regimes were later also considered intellectual property, we need to focus on those aspects that make this inclusion intelligible. The transition from privileges on machines to patents on inventions was a complex phenomenon that involved the demise of political absolutism, development of liberal economies and the emergence of the modern political subject. To this historical mix of lines of development we can add the important role of textual patent requirements (Biagioli, 2006) and scale models of inventions (Pottage \& Sherman, 2010) in mediating the crucial distinction between immaterial inventive idea and its embodiment in the material artifact.

The modern conception of patent law emerged in the course of the eighteenth century and resulted in the passing of the first patent laws in France, England and the US. There was a shift from the old system of privileges

26 This view of genius echoes Edward Young's conjectures about the nature of originality more than a century before, who stated that an 'original may be said to be of a vegetable nature; it rises spontaneously from the vital roots of genius; it grows, it is not made' (Young, 1918, p. 7). 
granted by the sovereign, to patents as a kind of contractual right between the individual inventor and the public. Under the privilege system the machine that was the object of legal protection was an actual device situated at a specific location. The privilege contained some brief working requirements for the factual and technical examination of this machine. In the new patent rights system however, the patent document needed to contain extensive textual and pictorial specifications that no longer served for the examination but for the construction of the invention. ${ }^{27}$ The invention hereby became conceived as a publication, i.e. a tool for the disclosure of new knowledge so that the (skilled) public could study and repeat it. The object of legal protection was hereby transformed from an actual spatiotemporal material machine into an immaterial invention as a possible machine.

[These specification requirements] created the conditions of possibility for treating the actual material invention (the entity that used to be protected by early modern privileges) as separate from its 'idea' (the entity that would become protected by patent law). It was a paper item - the specification - that eventually put the 'intellectual' into 'intellectual property'. Allowing for the emergence of the idea as a distinct entity, specifications made possible for that idea to become the immaterial essence of the invention. This in turn recast the material invention (which previously had been the sole instantiation of the invention) as just one of the possible (and therefore inessential) embodiments of such an idea (Biagioli, 2006, p. 1143).

The immaterial idea and material embodiment of the invention thus become first constituted through the mediating role of legal specification requirements and the resulting descriptions and depictions in the patent document. In later developments, this immaterial essence of the machine becomes formulated as its 'principle' that could become embodied in several possible material machines. ${ }^{28}$ This notion served to distinguish the invention from abstract ideas in the philosophical sense, from principles discovered in nature in the scientific sense, and from concrete manufactured machines in the sense of engineering. ${ }^{29}$ The necessity to work out this principle eventually led to a need for lawyers to visually observe the material machines or their scale models in order to extract their immaterial 'mode of operation'. ${ }^{30}$

27 These specification requirements are first introduced in the United States Patent Act of 1790 and the French Patent Law of 1791.

28 The notion of the principle of the machine is first introduced in the United States Patent Act of 1793.

29 Biagioli, 2006, p. 1143.

30 Scale models of the invention have played a crucial mediating role similar to that of textual specification requirements. During patent disputes in court 
The shift towards the patent regime had further effects: it also transformed the figure of the inventor itself. Throughout the privilege regime the ideas which an inventor may have had about his invention were considered irrelevant for granting legal protection to machines, whereas in the patent regime these ideas become the essence of his invention. The inventor is hereby displaced away from the figures of the importer and the engineer who produce a material artifact or machine, towards the figures of the author and the genius who create an idea and its specifications. This transformation can be compared to the transition between printing privileges and copyright, with the difference that literary works had existed in textual form before the enactment of copyright laws, whereas inventions attained their textual form precisely due to the enactment of the patent laws and their specification requirements.

\section{Trademarks}

Trademark law is another legal regime that is classified as intellectual property. As a separate legal regime, trademark law historically developed considerably later than patent and copyright law and in more explicit relation to these other regimes. Whereas the use of marks of trade is usually dated all the way back to biblical times, the emergence of the modern regime of trademark law conceptualized as property rights took shape in the nineteenth century in Europe and the USA. These developments occurred in a period in which processes of industrialization were well underway and in which there was a slowly growing use and recognition of marks in practices of trade. More and more marks were put on products in order for the consuming public to unambiguously identify their producers and to distinguish them from both generic goods and the products of other producers. These developments fuelled an increased demand for the legal protection of trademarks as a separate legal regime. This led to a discussion on the nature of the legal trademark ${ }^{31}$ and several countries passed their first trademark laws, ${ }^{32}$ installed systems of registration and engaged in international treaties. Of special interest here are the relations with the regimes of copyright and patents throughout these discussions in Great Britain and the USA, in which there were pressures from different sides to include trademark within the framework of intellectual property.

or the examination at the patent office, they enabled the extraction of the principle out of a material machine as its immaterial essence (Pottage \& Sherman, 2010).

31 Bently, 2008.

32 France in 1857, Great Britain in 1862, USA in 1870 and Germany in 1875. 
Patents and copyrights also provided an important point of comparison in the process of formulating and interpreting trademark rights and, in the lack of any trademark-specific legislation, these regimes also provided the legal basis for pursuing court cases. ${ }^{33}$

Some commentators would however come to argue that there are important differences between these legal regimes, since trademarks had little to do with creation. The US lawyer Upton stated that:

The exclusive right of multiplying copies of original productions of the mind, whether in the form of books, maps, engravings, designs or other of the manifold emanations of human thought, expressed by words or symbols-bears no appreciable resemblance to a right of property in a mere name, figure, letter, mark, device or symbol - when used as a designation of a thing (Upton, 1860, p. 14).

There is no similarity between these regimes since copyrights deal with 'original productions of the mind' that did not exist before and the right granted is 'a property in the thing itself'. Trademarks on the other hand are merely words or images which were already in existence in common public use and are re-appropriated as 'a means of designating things'. These signs are thus not protected in themselves but in so far as they designate something else: a certain trade product. Upton states that a trademark 'has no existence apart from the thing designated'. Furthermore, it was also argued that trademarks had more to do with laws of forgery, fraud and unfair competition than with the protection of intellectual property. In this context it is interesting to see that Upton did speak about 'this peculiar character of property' in the well-earned reputation of trademarks.

This focus on reputation already indicates a later transition in trademark law and the function of trademarks as a 'salesman', ${ }^{34}$ which would occur with the increase in importance of advertising. ${ }^{35}$ In an important article Schechter argued that the injury to trademark infringements does not necessarily consist in the creation of confusion for consumers that diverts trade to another producer. Instead, the real injury

is the gradual whittling away or dispersion of the identity and hold upon the public mind of the mark or name by its use upon non-competing goods. The

33 Sherman \& Bently, 1999, pp. 168-72.

34 Schechter, 1927, p. 815.

35 Drescher calls this the change from the trademark as a sign that identifies and distinguishes its producer as the origin of a product, to the trademark as a symbol as 'a device to express the intangible values and attributes of a product' (Drescher, 1992, p. 339). 
more distinctive or unique the mark, the deeper its impress upon the public consciousness and the greater its need for protection against vitiation and dissociation from the particular product in connection with which it has been used (Schechter, 1927, p. 825).

The immaterial character of the trademark is here thus not located in the mind of its creator (like in copyright and patent law) but displaced and installed in the mind of the public. Schechter even speaks of the 'psychological hold on the public' which no longer depends only on the quality of the products but on the uniqueness of the mark and the advertising efforts of the trademark holder. He also introduces an element of creativity in trademark law. By the continued use of and investment in the trademark, the trader gains a favourable impression in the public's mind. Just as an author creates a work, a trader creates goodwill or reputation. Furthermore, a mark will only have a unique identity when it is original to the extent that its wording has been 'added to rather than withdrawn from the human vocabulary' (p. 829) ${ }^{36}$ On this conception a trademark is no longer devoid of a separate existence as Upton still maintained, but has become 'an agency for the actual creation and perpetuation of good will' (Schechter, 1927, p. 818).

\section{A Note on Legal Approaches}

Copyright laws emerged as a convergence of different historical developments: the dispersion of the invented printing press throughout European countries, the proliferation of copies on an economic market of growing literates, the systems of printing privileges of the old legal regimes, natural law theories on property, the romantic philosophies of authorship and political events like the French Revolution. The figure of the author hereby came to serve as a proprietor of a special kind of commodity: his work. The distinction between immaterial form and material embodiment played a comparable role. This immaterialization function is a vector of appropriation for literary creation or technological invention, both of which necessarily always occur outside of the law. It serves to internalize these creative movements and make them legally manageable by abstracting an immaterial identity and retroactively grounding this as a legally protected work or invention. The law can hereby come to govern localizable material entities now qualified as material embodiments or reproductions of an immaterial template.

36 For a critical discussion of these arguments, see Bently \& Sherman, 2009, pp. 717-18). 
Before we conclude this section, a short note on theoretical or methodological positioning is warranted, in order to understand the approaches pursued in explaining intellectual property concepts. Rose, Woodmansee, Hesse and Jaszi work out a certain historical nexus in which the figure of the author arose and attained a function of appropriation. Law was an instrumental strand in this contraction. ${ }^{37}$ Rose is the most engaged with this role of law by focusing on the legal debates on authorship and literary property in English courts in the eighteenth century. He gives account of the intra-legal arguments about 'the great cause concerning literary property' by which the new figure of the author arose. Woodmansee is concerned with Foucault's author function and the development of the concept of the author in the eighteenth century. Law here forms but a few footnotes in a complex web of philosophical, political, economic and esthetic strands. Hesse is much interested in the relationship between authorship and the law', this relation is however discussed in terms of extra-legal causalities. She states that the political event of the French Revolution 'reshaped the legal and political identity of the author' and that the concept of the author as proprietor arose 'as a result of the commercialization of the book trade' (Hesse, 1990, pp. 109-10). This kind of theoretical positioning comes out most explicitly in Jaszi. He is interested in how the notion of authorship influenced the law in the USA and tries 'to show how copyright received a constructed idea of "authorship" from literary and artistic culture' and how 'this "authorship construct" has been mobilized in legal discourse'. Jaszi performs an analysis from an 'external perspective' that takes its bearings from deconstructivism and post-structuralism in literary theory, in trying to reveal the concealed interests in the discussions on intellectual property. On this account, authorship is nothing but a 'culturally, politically, economically, and socially constructed category' with a set of values that derive from Romanticism (Jaszi, 1991, pp. 455-9).

There is an important difference on this point with the approaches by Biagioli and Pottage \& Sherman to the history of patent law. Whereas for the former the distinction between material and immaterial used in the law was (externally) imported from Romanticist philosophy, for the latter it is the product of an 'internal logic' of legal regimes and the mediating role of certain items and techniques like textual patent specifications and models of inventions. ${ }^{38}$ The strands of politics, economics and philosophy

37 The different roles these authors assign to law might also relate to the differences between Anglo-Saxon common law and Continental civil law systems.

38 Something similar pertains to Bently \& Sherman who argue that the historical legal changes in trademark law should not be conflated with the historical socio-commercial practices of applying marks to goods (Bently \& Sherman, 2009, 
do enter the picture here, but in a different, less determinative way. In our empirical analysis of intellectual property in technological inventions in the next chapters, we will focus on these mediating items for constituting patents as ideal templates that become distinguished from their material reproductions. ${ }^{39}$

\subsection{LEGAL DOCTRINE: FROM IMMATERIAL GOODS TO INFORMATION GOODS}

In this section we will discuss the further developments of the incorporeal things that are the subject 'matter' of copyright and patent laws, by treating some of the seminal works in legal doctrine on the theory of immaterial goods. This theory is both a continuation and a critique of the theory of intellectual property. We will start with Josef Kohler's initial framing of Immaterialgüterrecht. We will study how the theory consolidated in later doctrinal texts in which the immaterialization function achieved its most explicit formulation (Troller) and in which there eventually is a shift from immaterial goods to informational goods (Hugenholtz). The focus will be on the idea/expression or content/form distinctions and the corporeal/ incorporeal, tangible/intangible or material/immaterial distinctions.

\section{The Staging of Immaterial Goods}

Kohler developed his legal theory of immaterial goods in order to overcome some of the problems of the theory of intellectual property (Kohler, 1894). He argues that the term 'property' is limited to corporeal things, either movable things like commodities or unmovable things like parcels of ground, and cannot be easily transferred to incorporeal goods. In contrast to corporeal goods with their fixed borders, the scope of an original idea is not easily demarcated, which makes a different legal treatment necessary. The good created by the author (Autorsgut) has to be distinguished from the ideas that are already available and from productions without original character. But wherein resides the distinctive criterion of the quality of this Autorsgut, this object of the author's rights? Kohler responds to this question on a

p. 711). They accuse Schechter (1927) and Drescher (1992) of committing such a conflation.

39 In this context, it is interesting that Pottage and Sherman speak about the 'limitations of a speculative historical enquiry' for understanding the role of things in the overall historical ensemble of developments. They instead advocate an ethnographical method. Here a turn to legal practice becomes relevant. 
meta-level of doctrinal creativity, by extracting four legal stages of authorial creation from different art forms and places them in a hierarchy. Each implies a different relation between author and idea and increasingly grasps the essence of authorial quality (Kohler, 1880, pp. 166-77).

The first stage concerns the oral representation of ideas (Ideeendarstellung) externalized in language or another means of communication. The bound, measured way in which thoughts are shaped and expressed in a lecture can here be distinguished from the unbound, loose usage of everyday speech. The artistic quality of a work however, does not merely reside in linguistic form, but also has an inner form of shaping ideas (Ideeenbildung), which forms the second stage of authorial quality.

The most essential form is the inner form: the way the author approaches his ideas, how he groups them as main- and side-figures and stages them. It is the coloring under which the ideas stand out, like the figures in a painting, sometimes in clear contours, sometimes in the chiaroscuro of the more stimulating and suggestive, as executive and demarcating styles, sometimes in flash, sometimes in gentle lighting, with more or less clarity and perspective, with bigger or smaller distinction of the essential from the inessential background: this is the secret of every author, this is the atmosphere of his shaping of ideas [Ideeenbildung] [...] This form is not the inner form of language, but the form of the sequence of ideas, the grouping of ideas and the movement of ideas, the peculiar nature of the association, connection, and rejection of ideas, about the individual particularity of the mental mechanics in general (Kohler, 1880, p. 168, my accents).

The relation between author, creation and ideas is here transposed from oral speech in which the author represents an idea on the external plane of language in the clear and bounded form of its grammatical rules and vocabulary, to the plane of composition on which the author 'approaches' his ideas by their figural staging, lighting and colouring. The author function of creation has here changed from the art of oration to the arts of painting and theatre direction, and the relation between author and idea has changed from linguistic expression of ideas to their internalization as acting figures within a composition. Different artistic techniques are employed for these purposes. The author situates his ideas in relation to other ideas as main actors or side-figures, places them against a certain background and in a certain light, so that the idea is made to stand out. Ideas here attain the form of figures. Kohler calls the results of these 'mental mechanics' of artistic creation, the 'atmosphere of shaping ideas' ${ }^{40}$ Through the author's compositional activities of association, connection

40 This concept is similar to what Benjamin calls the 'aura' or 'atmosphere' of the work (Benjamin, 2008). 
or rejection of ideas, these ideas will form certain sequences and groupings and even dynamic developments, which constitute the artistic form of the work; its inner form.

The creations of poetic fantasy are located on a higher, third stage of authorial quality. Authentic creation does here not consist in the formation of external materials like the facts that scientists are often forced to treat in their works, but this material itself is the free creation of poetic fantasy. Great writers like Turgenjev, Homer and Shakespeare have created new images of life that undergo all kinds of psychic development. Not only the inner and external forms of the work, but also its individual content of ideas (Ideeeninhalt) are thus the object of authorial rights. Kohler calls this the imaginary image (imaginären Bild), which is the individual inner core of the work of art. This core lies behind the veils of speech and remains constant throughout the many changes in its subsequent adaptations and translations. Finally, the highest, fourth stage of authorial quality is musical. Kohler follows Schopenhauer in stating that where the other arts get their idea-elements (Ideeenelemente) from empirical perception of the objects of experience, music gets its ideas from the immediate intuition of a higher realm of existence beyond sensation. ${ }^{41}$

Kohler concludes that the rights of the author are not his intellectual property. It is a property-like right on an immaterial good: the imaginary idea-image, just like a patent right, is an immaterial good right (Immaterialgüterrecht) on inventive ideas. ${ }^{42}$ This link to patent law is not coincidental, since Kohler first formulated his theory on immaterial goods in his writings on patent law and later transferred it to copyright. In this theory, there is a distinction between the material thing (the book or machine) that is the object of property and the immaterial good that is the object of copyright and patent law.

\section{The Axiology and Power of Immaterial Goods}

The intellectualization of the legal object in Kohler's theory of immaterial goods has formed the basis for much of (Germanic) legal doctrine. The theory has found its full extrapolation in the voluminous

41 Schopenhauer elevated music to the highest form of art as 'a copy of the will itself', whereas all the other arts are copies of certain (Platonic) Ideas (Schopenhauer, 1954, p. 257).

42 Ulmer calls Kohler's theory of immaterial goods incomplete, since a work does not only have a relation of economic utility with its author, but also has an ideal tie with the author as its brainchild. It thus has a relation of paternity (Ulmer, 1960). 
Immaterialgüterrecht (Troller, 1983) by Troller and its condensation in his Kurzlehrbuch des Immaterialgüterrechts (Troller, 1978). We will study these doctrinal developments and touch upon the approach to legal phenomena they imply. ${ }^{43}$ Troller starts his 'general dogmatic considerations' with the position that the fixed points of legal order are legal subjects and legal objects, and that the legal game of rights and claims moves between the two. Within this traditional dogmatic framework however, immaterial goods behave with a certain resistance to being classified as legal objects and force the legal scholar to think about things unfamiliar to legal theory. The legal objects of immaterial goods are different from other legal objects due to their common character as intellectual things. Law has always recognized corporeal things as legal objects, for instance of property law. Incorporeal things however have never been protected to the same extent. One of the main tasks of Immaterialgüterrecht therefore is to determine whether technical and artistic achievements and distinctive signs can attain protection as a legal object according to general categories.

These preliminary remarks have already sketched a whole image of law and have paved the doctrinal path for the analysis of intellectual rights. According to Troller the legal continuum can be ordered according to an axis between the two extremes of legal subjectivity and legal objectivity. On the basis of this axis the whole dynamics of disputes, claims and rights can be assigned its legal co-ordinates, giving rise to the order of law. ${ }^{44}$ Within this order, the task of legal doctrine is to classify such claims and rights according to their object and subject. Troller is aware however, of a certain resistance of the objects of intellectual rights against such classification. Instead of taking this resistance as a theme for concrete investigation however, he makes it into a common trait of all these objects - their intellectual nature - in order to determine this nature after general categories.

Troller first compares immaterial goods to the res incorporales of Roman law in order to demonstrate the clear and distinct intellectual nature of the former. Res incorporales are rights or collectives of things that have corporeal things as their immediate substrate, or things equivalent to money or certain achievements. These things (res) only acquired 'incorporeal' quality through techniques of legal abstraction. All the

43 Whereas Kohler's writings are characterized by a certain fluidity of writing with creative excursions, Troller wants to institute immaterial goods as a doctrinal legal system.

44 With Deleuze and Guattari we can call this an arborescent schema of law in which all the movements of legal practice are subjected to a line drawn between two pre-fixed points, instead of passing in the middle between such points (Deleuze \& Guattari, 1987, pp. 292-6). 
goods designated by the term 'res incorporales' are submitted to the laws of the corporeal world and are thus limited in time and space. On the contrary, the term 'immaterial good' refers to things of an intellectual nature like artistic works, technical rules, models or distinctive signs, and neither represent corporeal things on a conceptual level nor through legal techniques. These categories of immaterial goods have in common their independence in relation to space and time. ${ }^{45}$

The establishment of the intellectual nature of immaterial goods has important consequences. According to Troller, their independence from corporeal fixation assures these goods a 'particular power' and provides them with a potential ubiquity. An invention can serve in all countries as a rule for the unlimited fabrication of merchandise or execution of activities. A literary, musical or artistic work can be represented in different places in the world at the same moment. The use of a distinctive sign of an enterprise reinforces its capacity as authoritative referent. All immaterial goods can quantitatively be indefinitely repeated in space and time and 'can be communicated without losing in substance and quality, no matter where, when or how often one submits them to the aid of sensorial perceptible signs' (Troller, 1978, p. 34). The corporeal thing is a mere medium for the transmission of the self-identical immaterial good that itself remains unaffected by this process. We could call this the strong position on immateriality, which also presupposes particular theories of communication and representation.

After having established their common intellectual nature, Troller can enter into the particularities of the different kinds of immaterial objects. He observes that not all kinds of immaterial goods (scientific discoveries) merit legal protection and that it is therefore necessary to understand each of these subcategories precisely. Discoveries, technical works and esthetic works all constitute immaterial goods, but have to be clearly distinguished. The particularity of each of these objects resides in their material fundaments and legal nature. Troller notes that there is a 'difficulty' here relating to the fact that legally protectable immaterial goods do not correspond to corporeal objects or even to purely intellectual objects in an extra-legal sense. The concepts for these immaterial objects are not taken from the domains of technique or art, but are established by law itself. Whereas in many legal fields the legal definition of concepts is sufficient to

45 It does not become clear how these immaterial goods acquired independence from corporeality and how res incorporales did not. This is unfortunate since the distinction is crucial for the success of the theory of immaterial goods. We will see that such a comparison might backfire by making the immateriality of these goods also dependent on legal techniques dealing with spatiotemporal matters. 
determine the relevant legal aspects of things without recourse to experts, this is not the case in the law of immaterial goods. Here, the lawyer is often not able to determine the essential attributes through legal method, but has to address experts in the profession in question, like technicians in the case of patents. Thus, 'it is indispensable that lawyers, within the law of intellectual property, possess the faculty to understand the techniques, commercial acts or the characteristics of esthetical creations. Only the one who satisfies this qualification can find access to the material fundaments' (Troller, 1978, p. 59) of these immaterial goods.

Troller again runs into a 'difficulty' when working out the commonality between all immaterial goods, which is related precisely to the fact that here we are situated on the plane of law with its specific legal exigencies in dealing with the specific materialities of conflicts. On this plane we will not find immaterial goods, but just 'works', 'inventions', 'trademarks' which are legal concepts. When immaterial goods are first made totally independent from everything including law and material fundaments, but are then installed as legal concepts, one will indeed confront an insurmountable problem of correspondence between these concepts and supposed extra-legal things. Experts would then indeed be called for to bridge this gap of correspondence from the outside. In the end, it is indeed indispensable for lawyers to acquire an understanding of the 'domains' under their consideration. The 'difficulty' thus lies elsewhere in the theoretical pre-positions. Troller's foundational moves start from commonality between these domains: the postulated shortcut to the existence of immaterial goods and their common character as intellectual things fixed between the two juri-axiomatic points of legal subjectivity and legal objectivity. In this way one presupposes what would still have to be investigated and established when one sets out to constitute the theory of immaterial goods. The ones who should actually acquire a sense for the concrete materiality and legality are the legal theorists not the legal practitioners! Only in this way can the legal theorist have access to the material fundaments of these immaterial goods.

\section{The Work as Information Good}

The theoretical developments of immaterial goods can be pursued a step further into the domain of the information society, with regard to the relation between intellectual rights and information. In his dissertation Hugenholtz, confronted with the ubiquity of information ${ }^{46}$ and its

46 He even states 'our life depends on information. Information determines our actions and our total existence' (Hugenholtz, 2005, p. 1). 
economic value, sets out to determine whether factual information can be protected by copyright, 'since information is preeminently a copyable immaterial product' (Hugenholtz, 2005, p. 4). Considering that the term information has a range of different meanings, Hugenholtz proposes to interpret it in its classical semiotic sense as a message that is communicated through a physical medium and increases knowledge in the receiver. Information is hereby fixed under the threefold structure of syntax, semantics and pragmatics as: formal arrangement, meaningful content and practical effect.

Hugenholtz argues that works can also be interpreted in this way and that from this perspective it has several elements of form: a transmission form determined by the type of communication; a syntactical form as a specific configuration of signs (letters, words, symbols); a semantic form as the reference of the work to its content; and a pragmatic form that determined how the work is appreciated by the receiver. He proposes to replace the duality between content and form of classical copyright theories (like Kohler's) by the semiotic threefold of sign, reference and referent. This distinction can hereby be reconceptualized as a difference between information and data developed in (semiotic) information theory. Copyright thus does not protect data or facts but only information and this leads Hugenholtz to assert that 'each work has the character of information' (Hugenholtz, 2005, p. 60). Both work and information are immaterial objects. The immaterial good that Kohler and Troller referred to actually is information and we should henceforth better speak of information goods.

\section{$* * *$}

This section focused on the grounding of immateriality or intellectuality in the development of the theory of immaterial goods. Different disciplines, models and figures were resorted to in order to constitute and work out the immateriality of intellectual goods. We have seen the first figural staging of these immaterial goods by Kohler in a correction of the theory of intellectual property. He developed the qualitative forms of authorial creations by passing through models from the arts: speech for the work's outer form; painting and theatre for the work's inner form; poetry for the imaginary image of the work; music for the creative intellectual intuition. These different forms of artistic creation were then subjected to a hierarchy based on gradients along the sensation-intellection axis, the so-called stages of authorial quality. Furthermore, Kohler grounds the central distinction between the material representation and immaterial being of the work on (Schopenhauer's) philosophical theories. 
These figures of authorial creation, which were still dynamically staged in the writings of Kohler, became condensed into static forms of doctrinal statement in the legal theory of Troller. Immaterial goods were assigned their location on the axis of legal order through a range of doctrinal pre-positions, suppositions and positions. The common trait between the different subcategories of immaterial goods - works, inventions and trademarks - was their intellectual nature. Immaterial goods acquired an independence from spatiotemporal corporeal things and gained a force of proliferation through representation and communication.

In Hugenholtz the intellectual work of copyright becomes itself transformed into information within the exercise of determining the relation between copyright and information. The immaterial good turns out to be an information good. This change was achieved through the semiotic concepts of the communication of information in which information is taken as a structured sign (or a message) which is communicated through a physical medium, has a signification for a receiver within a certain context and refers to a signified in the non-communicable outside world. Under the threefold aegis of syntax, semantics and pragmatics, the distinction between content and the different forms of the work of copyright theory is transformed into the distinction between the facts and information of information theory. 